\title{
TO A QUESTION OF ARCHITECTURE OF PSYCHOTHERAPY SYSTEMS
}

Курило В. 0.

Курило Віталій Олексійович
Запорізький державний медичний університет МОЗ України, вул. Сєдова, 31, м. Запоріжжя, 69035, Україна e-mail: v.kurilo@i.ua; ORCID 0000-0001-6579-8306

\section{TO A QUESTION OF ARCHITECTURE OF PSYCHOTHERAPY SYSTEMS}

Abstract: $\quad$ The task of the study was to analyze the problems of structuring a psychotherapeutic clinic and highlight the optimal structure of the stages of the psychotherapy system. To this end, a content analysis of existing ideas on the research topic was conducted. The results of the study demonstrate the state of psychotherapy as a clinical and scientific discipline in our time. The systematic use of contingent-specific combinations of psychotechnics determines the most relevant, at the moment, approach to structuring a psychotherapeutic clinic. Nevertheless, the issues of ergonomics and congruence both in relation to the object - the target contingent, and to the subject - the personality of the psychotherapist - receive the illumination only in separate studies. This list of conceptual studies sets is the general vector of methodological consolidation and disciplinary attribution of psychotherapy, transforming a disparate set of communicative practices, as it was at the beginning of the 21 st century, into a clinical discipline that requires implementation of a systematic approach from the methodology that appeals to it. The study formulates the key questions, which are designed to determine the role and content of psychotherapy as a clinical discipline. The analysis of the existing systems of psychotherapy is carried out and their main features and global shortcomings are highlighted. The modern concept of the "psycho-phenomenological profile", was designed to improve the psychotherapeutic process, was reviewed and analyzed. The optimal stages of the psychotherapy system and their components were highlighted.

Key words: $\quad$ psychotherapy, psycho-phenomenological profile, psychotechnics, stages of the system of psychotherapy

\section{ДО ПИТАННЯ ПРО АРХІТЕКТУРУ СИСТЕМ ПСИХОТЕРАПІЇ}

Анотація: $\quad$ Завданням дослідження стало проаналізувати проблеми структурування психотерапевтичної клініки та виділити оптимальну структуру етапів системи психотерапії. 3 цією метою було проведено контент-аналіз існуючих уявлень з теми дослідження. Результати демонструють уявлення про стан психотерапії як клінічної та наукової дисципліни в наш час. Відзначено, що систематичне використання контингент-специфічних комбінацій психотехнік визначає найбільш актуальний на даний момент підхід до побудови психотерапевтичної клініки. Проте, питання ергономіки і конгруентності, як по відношенню до об'єкта - цільового контингенту, так і до суб'єкту - особистості психотерапевта висвітлюються тільки в окремих дослідженнях. Цей список концептуальних досліджень встановлює загальний вектор методологічної консолідації та дисциплінарної атрибуції психотерапії, перетворюючи розрізнений набір комунікативних практик, як це було на початку 21-го століття, в клінічну дисципліну, яка вимагає застосування системного підходу, заснованого на методології психотерапії. У дослідженні сформульовані ключові питання, які покликані визначити роль і зміст психотерапії як клінічної дисципліни. Проведено аналіз існуючих систем психотерапії та виділені їх основні риси і глобальні недоліки. Розглянуто та проаналізовано сучасну концепцію «психофеноменологічного профілю», яка покликана поліпшити психотерапевтичний процес. Виділено оптимальну структуру етапів системи психотерапії та їх компоненти.

Ключові слова: психотерапія, психофеноменологічний профіль, психотехніки, етапи системи психотерапії 


\section{К ВОПРОСУ ОБ АРХИТЕКТУРЕ СИСТЕМ ПСИХОТЕРАПИИ}

Анотація:

Задачей исследования стало проанализировать проблемы структурирования психотерапевтической клиники и выделить оптимальную структуру этапов системы психотерапии. С этой целью был проведен контент-анализ существующих представлений по теме исследования. Результаты исследования демонстрируют представление о состоянии психотерапии как клинической и научной дисциплины в наше время. Отмечено, что систематическое использование контингент-специфических комбинаций психотехник определяет наиболее актуальный на данный момент подход к построению психотерапевтической клиники. Тем не менее, вопросы эргономики и конгруэнтности как по отношению к объекту - целевому контингенту, так и к субъекту - личности психотерапевта освещаются только в отдельных исследованиях. Этот список концептуальных исследований устанавливает общий вектор методологической консолидации и дисциплинарной атрибуции психотерапии, превращая разрозненный набор коммуникативных практик, как это было в начале 21-го века, в клиническую дисциплину, которая требует применения системного подхода, основанного на методологии психотерапии. В исследовании сформулированы ключевые вопросы, которые призваны определить роль и содержание психотерапии как клинической дисциплины. Проведен анализ существующих систем психотерапии и выделены их основные черты и глобальные недостатки. Рассмотрена и проанализирована современная концепция «психофеноменологического профиля», призванная улучшить психотерапевтический процесс. Выделены оптимальные этапы системы психотерапии и их компоненты.

Ключевые слова: психотерапия, психофеноменологический профиль, психотехники, этапы системы психотерапии

Introduction. Current trends in the field of psycho-disciplines determine the need for highlighting and a more detailed understanding of the structure of psychotherapy systems and their clinical content, as well as standardization of psychotherapeutic techniques, and optimization of approaches to their choice.

Psychotherapy is a rapidly changing discipline. This causes the difference of ideas about it, its methods and methods of research at the beginning of its inception and in modern times. If at first psychotherapy consisted of separate isolated techniques that were practiced by psychologists or psychiatrists as additional methods to the main treatment, today we can speak about the formation of psychotherapy as an independent separate scientific and clinical discipline; The subjects of psychotherapy are already not psychologists and psychiatrists, but qualified psychotherapists.

At present, a definite idea has been formed about the stages of psychotherapy systems and their content. However, these steps require further improvement and scientific justification.

Psychotherapeutic interventions are carried out after the diagnosis of a mental disorder and its causes. The clinical diagnosis determines the amount of psychotherapy. However, sometimes there are deviations from this rule and psychotherapy is not aimed at treating a mental illness as a whole, but at correcting one of its symptoms.

The role of psychotherapeutic correction may be different: it may occupy a leading place in the medical complex; used as an additional method; be aimed at eliminating the internal picture of maladjustment (the reaction of the individual), as well as at the rehabilitation and psycho-prophylaxis of the patient $[1,2]$.

Depending on this, psychotherapy techniques are selected according to the indications and the contraindications using a personalized approach or using a standard algorithm $[3,4]$.

The answer to the conduct of psychotherapeutic interventions is the emergence of patient-specific phenomena, which can be both sanogenic and destructive.

Psychotherapeutic phenomena are established and described primarily by empirical means. Most of them have purely psychological interpretations. In psychotherapy, attempts have been repeatedly made to objectify the conceptual-conceptual apparatus. However, this objectification was nevertheless more likely experimental and registration in nature and was carried out, moreover, under only one visual control $[5,6]$.

To understand the process of psychotherapeutic treatment and the 
mechanisms of the effectiveness of psychotherapy, V. V. Chugunov and B. V. Mikhailov introduced the concept of the clinical psychotherapeutic effect syndromes - a complex of clinical, psychological, behavioral manifestations arising in the process or as a result of the implementation of a particular method of psychotherapy. The authors also conducted a study to identify associations between methods of psychotherapy and sanogenic psychotherapeutic phenomena [5, $6,7]$.

In view of the above, it can be argued that psychotherapeutic diagnosis in all its diversity occupies a special place in the systems of psychotherapy. Each of the methods of psychotherapy offers its diagnostic apparatus of various levels of complexity and originality. In modern psychotherapy, sets of methods and provisions for psychotherapeutic diagnosis have been formulated and proposed [204, 205].

It should be noted here that psychodiagnostics usually precedes the therapeutic stage of psychotherapy, however, cases of additional diagnostics are not excluded as far as psychotherapy is concerned; psychodiagnostics on completion of psychotherapy is no less relevant, which raises the question of optimal phasing in psychotherapy systems, which is not fully understood.

Therefore, the task of the psychotherapist is a comprehensive psychotherapeutic examination of the patient and the selection of the most appropriate psychotherapeutic method for the patient in order to avoid the occurrence of destructive phenomena in the patient in response to psychotherapy. The right combination of psychotherapy methods and their staging within the framework of the psychotherapy system is also very important.

This requires an in-depth analysis of the architecture of psychotherapy systems, which will help the psychotherapist to solve his tasks.

The purpose of the article was to analyze the problems of structuring a psychotherapeutic clinic and highlight the optimal structure of the stages of the psychotherapy system.

Methods used during research. A content analysis of existing ideas on the research topic was conducted.

Results and discussion. The systematic use of contingent-specific combinations of psychotechnics determines the most relevant, at the moment, approach to structuring a psychotherapeutic clinic. Nevertheless, the issues of ergonomics and congruence both in relation to the object - the target contingent, and to the subject the personality of the psychotherapist - are regarded only in separate studies like the concept of clinical-psychophenomenological method, clinical-psychotherapeutic effectsyndromology, psychotherapeutic diagnosis, psychophenomenological profile [5 - 9].

This list of conceptual studies sets is the general vector of methodological consolidation and disciplinary attribution of psychotherapy, transforming a separate set of communicative practices, as it was at the beginning of the $21 \mathrm{st}$ century, into a clinical discipline that requires implementation of systematic approach from appealing to its methodology.

The analysis of clinical studies of the last decade, conditionally attributed to the competence of medical psychology, but de facto being psychotherapeutic on the basis of clinical contingent's presence, demonstrates the paradigmality of the psychotechnics' combining into the "psychotherapy`s system", the structure and content of which varies depending on contingent and referential (at the time of the study) level of therapist's qualification requirement. Thus, some questions arise that have become traditional in the framework of discussions of this kind:

1. How was the selection of psychotechnics done, and was it possible to predict their effectiveness before obtaining empirical data?

2.What are the requirements to the competence of the specialist realizing a developed system, which often combines disparate methods of psychological correction and psychotechnics belonging to different and often confrontational psychotherapeutic paradigms?

3. Is absolute nomothetism possible in the context of a group of people, formed on the basis of a single factor - the presence of a specific pathology, under conditions of absence of data on their ethno-cultural, social, genodyspositional, psycho-constitutional and even gendered characteristics?

4. Are the requirements to the originality of each developed psychotherapy system acceptable? Does the formal side of the question of standardization and optimization of psychotherapysystems'structure not deprive its contingent-independent stages or components?

Academic necessity generates traditional answers to this list of issues. So the effectiveness of the psychotechnics' combinations, their congruence to the contingent is always confirmed by post factum bare empiricism, ergonomics and formal qualification requirements to the professionalism of the therapist, within the framework of the current legislation, while the firmness of the scientific 
novelty principle according to original researches is not discussable at all. Naturally, the question about acceptability of "discipline" nomination to the sphere of activity based solely on empirical data and formal sociallydetermined requirements, arise.

Meanwhile, psychotherapy at this stage of discourse development has passed the protodisciplinary threshold, having its own, systematized categorial apparatus, diagnostic and prognostic tools. Thus, for the mixing of dissimilar elements become eclectic, the architecture of psychotherapy systems should be considered in a disciplinary perspective.

An analysis of existing psychotherapy systems shows their absolute centering on a specific contingent. Such systems include a number of stages (in case of sequential design) or components / vectors (in case of parallel design), leaving out of focus the methodology of contingent selection and psychotechnical support. This question seems particularly contrasted in studies carried out with the participation of elderly and senile patients, under conditions of absence of data on sensory and cognitive-gnostic self-dependence of the contingent; the majority of such systems include the group stage, according to rationalization requirements of therapeutic process. Moreover, a cursory analysis of the last 10 years investigations indicates an average efficiency fluctuating among $60-80 \%$ of the involved contingent, which can be explained only by the presence of a certain rational qualification during the formation of the "study group".

On the other hand, there is the already stated question about the predicting of the effectiveness of psychotechnical support combinations. In case of absence of a rational solution to this issue, clearly there must be a significant dissonance between the number of conducted studies and effective original psychotherapy systems, but is not observed in practice.

Thus, in any psychotherapy system presented, there should be an obligatory pretherapeutic stage describing the qualification of transition to the therapeutic stage for the examined contingent, or the description of options for adapting psychotherapy procedure.

The decision allowing to standardize this stage of psychotherapy is suggested in the concept of "psychophenomenological profile", within the framework of which are diagnostic instruments, including the protocol of sequential application of psychotherapeutic tests, were developed, allowing the quantitative evaluation of one's mental activity features from the perspective of their congruence to the basic methods of psychotherapy, that when compared with the general contingent data allows to avoid inclusion of non-priority psychotechnics, or to formulate the rational requirement $[7,8]$.

The most important aspect of this mode of forming the pre-therapeutic stage of psychotherapy system is the possibility to avoid total individualization of the obtained data. Thus, it is possible to predict the effectiveness of psychotechnics' combination by comparing a group contingent's psychophenomenological profile with individual profile, without polyaxial analysis of patient's personological and psychofunctional characteristics.

The additional advantage of psychophenomenological profile's diagnostic apparatus is the fact that psychotherapeutic tests are analogous to psychotherapeutic session, and their results depend on current level of compliance; that also helps to avoid analytics aimed at establishing sufficient level of compliance, which is obligatory under any other conditions.

The therapeutic stage structure of psychotherapy systems varies greatly depending on contingent nature. Such variability, for all its validity (dictated, as it was already noted, by the requirements of scientific novelty), does not allow to form a single template covering the optimum of possible pathogenetic factors and to maximize the sanogenic effect. Additionally, this process is hampered by the stereotypic separation of psychotherapy, psychoprevention and psychorehabilitation.

Summarizing the optimal structure of psychotherapy system's therapeutic stage, without artificially dividing into psychorehabilitation and psychoprophylaxis, it is necessary to distinguish such components, in addition to original and specifically oriented pathologies:

- preventing of hospitalism range phenomena (including the maintenance of a rational stereotype of communication with a psychotherapist);

- genodyspositional sanitization (correction of family disadaptation, inevitable in cases of clinically perceptible psychopathology);

- prevention of stigmatization (including autotigmatization);

- prevention of nosogenic psychotraumatic factors and correction of existing ones;

- teaching of autodiagnostic procedures' conducting (for the purpose of pathological states self-indicating and prompts applying for specialized care); 
- procompliant impact;

- desensitization of recurrent and residual phenomena;

- rationalization of medical-social and formal-status consequences of the disease.

Conclusions. The study provides an analysis of existing ideas about psychotherapy as a clinical and scientific discipline from the beginning of its formation to our time. The key questions, which are designed to determine the role and

\section{References}

1. Lee P. T. Narrative synthesis of equine-assisted psychotherapy literature: Current knowledge and future research directions / P. T. Lee, E. Dakin, M. McLure // Health and social care community. - 2016. - № 24 (3). - P. 225-245.

2. Landrø N. I. Towards personalized treatment of depression: a candidate gene approach / N. I. Landrø // Scandinavian journal of psychology. - 2014. - № 55 (3). P. 219-224.

3. Madelin R. Personalizing therapy / R. Madelin // Cyberpsychology, behavior and social networking. 2014. - № 17 (6). - P. 333.

4. Testad I. The value of personalized psychosocial interventions to address behavioral and psychological symptoms in people with dementia living in care home settings: a systematic review / I. Testad, A. Corbett, D. Aarsland, K. O. Lexow // International psychogeriatrics. 2014. - № 26 (7). - 83-98.

5. Чугунов В. В. Диагностика в психотерапии и психотерапевтический диагноз: [Учебное пособие] / В. В. Чугунов. - Х. : Наука, 2010 - 304 с.

6. Чугунов В. В. Клинико-психофеноменологический метод / В. В. Чугунов, Б. В. Михайлов // Медицинская психология. - 2010. - № 2. - С. 3-15.

7. Чугунов В. В. Клиника и дисциплинарная история психотерапии / И. И. Чугунов. - 2-е изд. стереотипн. - К. : Здоров'я ; Х. : Око - Наука, 2008. - 768 с.

8. Чугунов В. В. Метапарадигмальная модель сентенционно-семантической интервенции в сфере компетенции психотерапии / В. В. Чугунов, Ю. И. Заседа, А. Д. Городокин // Медицинская психология. 2014. - № 4. - С. 62-66.

9. Чугунов В. В. Феноменные «линейки» как систематические элементы психофеноменологического профиля (психотехническое наполнение, систематика, терапевтическая компетентность) / В. В. Чугунов, Ю. И. Заседа, А. Д. Городокин // Психиатрия, психотерапия и клиническая психология. - 2015. - № 2 (20). - C. 74-85.

Курило Виталий Алексеевич - Запорожский государственный медицинский університет МЗ Украины, ул. Седова, 31, г. Запорожье, 69035, Украина content of psychotherapy as a clinical discipline had been formulated. The analysis of the existing systems of psychotherapy is carried out and their main features and global shortcomings had been highlighted. The optimal stages of the psychotherapy system and their components had been highlighted. The study aims to raise current issues of modern psychotherapy, in order to improve its development as an independent scientific and clinical discipline.

\section{References}

1. Lee P. T., Dakin E., McLure M. Narrative synthesis of equine-assisted psychotherapy literature: Current knowledge and future research directions. Health and social care community, 2016, no. 24 (3), pp. 225-245.

2. Landrø N. I. Towards personalized treatment of depression: a candidate gene approach. Scandinavian journal of psychology, 2014, no.55 (3), pp. 219-224.

3. Madelin R. Personalizing therapy. Cyberpsychology, behavior and social networking, 2014, no.17 (6), pp. 333.

4. Testad I., Corbett A., Aarsland D., Lexow K. O. The value of personalized psychosocial interventions to address behavioral and psychological symptoms in people with dementia living in care home settings: a systematic review. International psychogeriatrics, 2014, no. 26 (7), pp. 83-98.

5. Chugunov V.V. Diagnostics in psychotherapy and psychotherapeutic diagnosis: [Tutorial]. Kharkov: Science, 2010, 304 p. (In Russ.)

6. Chugunov V. V., Mikhailov B.V. Clinico-psychophenomenological method. Medical psychology, 2010, no. 2, pp. 3-15. (In Russ.)

7. Chugunov V. V. Clinic and disciplinary history of psychotherapy. 2nd ed. Stereotypical. Kiev: Zdorov'ya; Kharkov: Oko-Science, 2008. 768 p. (In Russ.)

8. Chugunov V. V. Zaseda Yu. I., Gorodokin A. D. Metaparadigmatic model of the sentencesemantic intervention in the sphere of psychotherapy competence. Medical Psychology, 2014, no. 4, pp. 6266. (In Russ.)

9. Chugunov V. V. Zaseda Yu. I., Gorodokin A. D. Phenomenal "rulers" as systematic elements of the psycho-phenomenological profile (psychotechnical content, systematics, therapeutic competence). // Psychiatry, psychotherapy and clinical psychology, 2015, no. 2 (20), pp. 74-85. (In Russ.) e-mail: v.kurilo@i.ua; ORCID 0000-0001-6579-8306 